\title{
PM10 EXCEEDANCE IN BULGARIA
}

\section{Iliyana Naydenova ${ }^{1}$, Tsvetelina Petrova ${ }^{2}$, Rositsa Velichkova $^{3}$, Iskra Simova ${ }^{4}$}

\begin{abstract}
Despite the effort done by member states during the last decade, failure in the implementation of the Ambient Air Quality Directive is being continuously registered in many European cities for different air pollutants. One of the biggest concerns in Bulgaria is the exceeded PM10 concentration in the ambient air, measured in all six air quality zones during the winter period. This has induced numerous activities (at the national and European level) focused on the following issues: identification of the level of exceedance of the air quality norms for PM10; the general emission sources; the most prominent omissions and discrepancies in the legislative framework; the level of implementation of the prescribed measures and many others. However, the PM10 exceedance is still of a significant concern in at least 28 municipalities in Bulgaria. Thus, the present work introduces a brief report on the current state of the problem in the country. For that purpose, benchmarking analyses was applied for obtaining the range of discrepancies and the tendencies of the PM10 concentrations, monitored in the ambient air at the affected municipalities. The investigation was carried out using merely officially reported and freely accessible data and covered a relatively short period of time of six years. The latest national and European environmental reports present data confirming the primary role of residential heating and transport during the winter period as well as at the occurrence of particular atmospheric conditions.
\end{abstract}

UDC Classification: 6; DOI: http://dx.doi.org/10.12955/cbup.v6.1305

Keywords: particulate matter, $\mathrm{PM}_{10}$, ambient air quality.

\section{Introduction}

Although the air quality improved considerably during the last decades (EEA, 2017), numerous European cities still struggle handling high health risk caused by unregulated emissions of harmful substances in indoor and outdoor air as it was reported by WHO (2005), Schmidt and Zellner (2010), Dimitriou (2017) and Colom-Díaz (2017). Fine particulate matter (PM) like $\mathrm{PM}_{10}$ and $\mathrm{PM}_{2.5}$ often exceed the limit values, prescribed in the Directive 2008/50/EC. In fact, the particulates are the main pollutants, which concentration in the ambient air exceeds the required values for preservation of human health over many cities of the territory of the European Union (EU) see EEA (2015) and Schmidt and Zellner (2010). The harmful health effects related to PM depends mainly on the size, the morphology, and the chemical composition of the suspended particulate matter and those adsorbed on the particle, including teratogens, mutagens, desoxyribonucleic acid - modulators and other, - (Fuzzi 2006 ,2015; Colom-Díaz, 2017; Megido, 2016; Chernyshev, 2018; Czech, 2018). The EU Member states normally report industry, transport and energy as the main sectors of anthropogenic emissions of dust and fine particulates (EEA, 2017). Thus, air pollution is typically controlled by applying a twofold approach. First it aims at controlling the emissions at their sources and thereafter the concentration of a given pollutant in the affected environmental element.

This work was focused on the $\mathrm{PM}_{10}$ exceedance in the ambient air. The research was mainly influenced by the facts, reported by the National Report on the Status and the Protection of the Environment of Bulgaria (NRSPE ,2017). Therein it is stated that above $88 \%$, or 3.5 million, of Bulgarian citizens leave irregularly increased $\mathrm{PM}_{10}$ levels. Thus, the European commission (EC) has undertaken activities to protect citizens from air pollution,. (EC Press release, 2018), aiming to diminish the obtained breaks from the European legislative framework also in the Bulgarian legislation.

According to the same publications, in (NRSPE,2017) or in (EEA, 2017a), which are based on data representative for 2015 , about $46 \%$ of the emissions of $\mathrm{PM}_{10}$ originate from the sector of residential/household heating; about $32 \%$ - noncombustible industrial processes and product use; less than $9 \%$ - from energy production and distribution, in particular thermal power plants (TPP); and about $5 \%$ and $6 \%$ from road and other transport respectively. In the same reports, the sector residential/household heating is considered to be responsible for about $80 \%$ of the $\mathrm{PM}_{2.5}$ emissions.

\footnotetext{
${ }^{1}$ College of Energy and Electronics, Technical University of Sofia, Bulgaria, inaydenova@tu-sofia.bg.

${ }^{2}$ College of Energy and Electronics, Technical University of Sofia, Bulgaria, tzvetelina.petrova@tu-sofia.bg.

${ }^{3}$ Faculty of Hydroaerodynamics and Hydraulic Machines, Technical University of Sofia, Bulgaria, rositsavelichkova@abv.bg.

${ }^{4}$ Faculty of Hydroaerodynamics and Hydraulic Machines, Technical University of Sofia, Bulgaria, iskrasimova@gmail.com
} 
However, the latest Bulgaria's Informative Inventory Reports (IIR, 2017,2018) and the NFR tables (2017) and NFR tables (2018), do not contain data for the sector of significant importance: NFR 14 code: 1A4b ii-Sector Residential: Household and gardening (mobile). These reports present emission data that are officially reported within the Convention of Long Range Transboundary Air Pollution and under the Directive (2016/2284/EU). As confirmed by (Tista, 2017), the emissions therein are reliable, because they are updated annually for all sources, using the same methodology etc., but they are typically based on a top-down approach (except for the point's sources). Therefore, as discussed in (ETC/ACM, 2013), these emission data often appear to be insufficient for investigating the emission dynamics of sectors like residential heating (NFR 14 code: $1 \mathrm{~A} 4 \mathrm{~b}$ ii). According to the same authors the so called dynamic emissions are characterized by large spatial variability as well as temporal variability (yearly, weekly and sometimes daily). Furthermore, the authors pointed out that the appearance of such emissions is with mixed primary or secondary origin. It is often associated with increased use of wood for residential/household heating or road's sanding and salting during the very cold periods of the year; intensive use of fertilizers in spring; biogenic volatile organic compounds (VOC) released by vegetation in summer periods and many others.

Because the PM is mainly formed due to incomplete combustion, according to (Schmidt and Zellner, 2010) about $90 \%$ of the primary PM is formed in the combustion chambers of installations used for residential heating typically burning coal, wood or other e.g. biomass derived fuels. Besides the latest progress in EMEP/EEA (2016), emission factors suitable for reliable emission inventory or modeling purposes still require thorough investigation. The combustion byproducts take part in numerous complex mechanisms including processes like: coagulation, agglomeration, condensation, resublimation and gas-phase reactions - (Baumbach, 1990; Warnatz, 2006; Agafonov, 2007). As observed in (Faravelli, 2013; Jones, 2014; Wang, 2014 Czech, 2018) wood and biomass based solid fuels contain high concentrations of volatile organic compounds (VOC). (Branco and Costa ,2017) have investigated the effect of a fuel's particle size (agricultural residues) on their burnout rate, chemical composition and emissions of PM in a drop tube furnace. The observations show that the fuel particles with the largest size class studied (100-200 mm) experienced the highest burnout rate, whereas minor influence was obtained for the fuel's chemical characteristics and the temperature profile. At the same time moderate influence was denoted on the PM emissions in the flue gases.

As described in the papers by (Bockhorn, 2009;, Schmidt and Zellner, 2010) considerable amounts of ultra-fine particulates, with mean particle diameter less than 1 micron, are formed during biomass combustion. These particles are known to exert an exceptionally harmful impact on the health of living organisms, because they are emitted in the ground layers of the atmosphere along with a cocktail of compounds with different composition, structure and reactivity (e.g. surface-active substances, their derivatives and many others). Once emitted in the atmosphere, all these substances participate in series of chemical and/or physical reactions related to the formation of various interim products. According to (Bockhorn ,2009; Fuzzi, (,2015) the aerosols that are emitted into the atmosphere exert influence over the intensity of solar radiation; average annual temperatures; size and composition of the water droplets, which changes the frequency and the intensity of precipitations as well as over time, periods of fogs and other.

Other sources of particulates, mainly soot, are diesel and gasoline (Otto) engines (Dallmann, 2014; Chernyshev, 2018; Wardoyo, 2018). The share of PM, obtained as a result of ground transport is significant. According to (Schmidt and Zellner ,2010) this sector generates the biggest emissions of $\mathrm{PM}_{10}$ and $\mathrm{PM}_{2.5}$ in areas where there is no residential heating. In the same work the authors stated that another frequently observed problem related to the PM exceedance in the ambient air where there are emissions of secondary PM that are directly related to the emissions of gaseous precursors like: $\mathrm{CO}$, $\mathrm{SO}_{2}, \mathrm{NO}_{\mathrm{x}}, \mathrm{NH}_{3}$ and $\mathrm{O}_{3}$. The interception with the emissions of benzo(a)pyrene and others or metal oxides, silicates, carbonates, transition metals and mineral particulates with natural origin were also discussed in (Schmidt and Zellner, 2010; ETC/ACM, 2013). Up to $50 \%$ of the total emissions of PM could be emitted through resuspension during winter road sanding, as well as through the wear of tires and brakes or road pavement activities.

Currently (Süring, 2016) have performed a quantitative analysis of allergens (antigens) accumulated over $\mathrm{PM}_{10}$ samples. Thus a specific kind of antigen (Bet $\mathrm{v} 1$ ) is established in predominating quantity during the seasons with active inflorescence. This result indicates that further to toxic substances, 
allergens are part of the composition and can be absorbed on the surface of $\mathrm{PM}_{10}$, which inhaled may be transported in the lower respiratory tract causing problems in particular in risk groups of the population living in urban zones with elevated PM levels.

It is well known that besides human activities, secondary PM emissions can be attributed also to natural sources involving sea salt, sulfates and others (Bruckmann, 2008; Fuzzi, 2015).

The problem with combustion generated PM, is that it requires the good will and appropriate funds for the implementation of sustainable technological solutions, suppressing their formation and emissions at the different stages of the combustion process. The control of emissions which are harmful for the environment, combustion byproducts can be attributed to conditions that must be achieved, leading to complete combustion of the relevant energy carriers. According to (Baumbach, 1990; Warnatz, 2006) a well-known fact is that the complete combustion (up to $\mathrm{CO}_{2}$ and $\mathrm{H}_{2} \mathrm{O}$ ) of a unit of fuel, at the relevant technology, requires the implementation of the three T-principle (time, temperature and turbulence). Nevertheless, in reality combustion still cannot be fully controlled, as well as the relevant emissions.

It is well known that adequate ambient air quality management requires reliable sources apportionment. According to the established procedures discussed in (ETC/ACM, 2013; Belis, 2015; Karagulian, 2015) numerous data is needed, which has to be validated in the context of the relevant quality assurance rules of procedures, according to (EMEP/EEA, 2016). Often it is accompanied by investigations of the particulates' chemical composition, their physical properties and structure. A massive number of experiments have been conducted on the topic over the last decade (Lipsky 2004; Bressi, 2013; Wang, 2014; Veleva, 2014; Manousakas, 2015; Fuzzi, 2015; Yatkin, 2016; Vicente, 2018), and many others). Thus, PM chemical composition has been characterized in the flue gas exhausted during the combustion of different fuels, (Lipsky ,2004; Bruchmueller, 2013; Colom-Díaz, 2017; Nielsen, 2017; Chernyshev, 2018;, Czech, 2018)) as well as in PMs sampled from the ambient air atmosphere, (Bressi, 2013; Veleva, 2014; Yatkin, 2016), or utilizing an appropriate numerical approach as discussed in (ETC/ACM, 2013; Ahlm, 2013;Gadzheva, 2013; Belis, 2015).

In their work (Manousakas ,2015) pointed out that control over the PM exceedance in the ambient air is an exceptionally important technological task for the attainment of which the study of the nature of the physical-chemical processes controlling the formation and the survival of these substances is needed, both in the course of the technological process and in their measurement in the atmosphere. Numerous publications on the best European practices that are often funded through the EU Funds, programs like LIFE, INTERREG, COST, and HORISON prescribe reliable approaches leading to sustainable ambient air quality improvement. The major steps to a successful ambient air quality management plan can be summarized as follows:

- Task 1: Determination of the level of exceedance;

- Task 2: Source apportionment;

- Task 3: Dispersion modeling and scenario optimization;

- Task 4: Identification of measures and funding instruments;

- Task 5: Ongoing and regular analyses are then needed, obtaining the level of implementation of the planned measures, the achieved results and the observed difficulties.

In case of failure, further revision is required, accompanied by actualization and implementation of the updated measures, until the requested air quality improvement is achieved, at the most cost-effective manner. The current study aims at summarizing the available data on $\mathrm{PM}_{10}$ exceedance that are currently being officially reported, thus supporting the implementation of Task 1.

Scope of the study

The present research is focused on the level of exceedance of the $\mathrm{PM}_{10}$, obtained in the ambient air of several Bulgarian municipalities. The study is based on benchmarking analyses of officially posted monitoring data, on the site of the Executive Environment Agency, namely the Quarterly Bulletins ExEA (2011-2016) and covers a relatively short period 2011 - 2016. In additions, the relevant data in the latest officially posted reports from (NRSPE, 2017; EEA, 2017a; IIR, 2017; IIR, 2018; NFR tables, 2017; NFR tables, (,2018) were studied. The results of the analyses revealed the level of discrepancies between the required and the actually measured limit values of $\mathrm{PM}_{10}$, the role of the major emission sources as well as the behavior of the $\mathrm{PM}_{10}$ pollution on a yearly basis. 
The list of the studied municipalities is as follows: Asenovgrad, Blagoevgrad, Burgas, Varna, Veliko Tarnovo, Vidin, Vratsa, Gorna Oryahovitsa, Galabovo, Devnya, Dimitrovgrad, Dobrich, Kardzhali, Lovech, Montana, Nesebar, Pazardzhik, Pernik, Pirdop, Pleven, Plovdiv, Radnevo, Ruse, Smolyan, Sofia Municipality, Sliven, Stara Zagora, Haskovo and Shumen. Geographically, these municipalities are situated in all six Ambient Air Quality Assessment and Management Zone/Agglomerations, specified by the Ministry of Environment and Water of Bulgaria, in accordance with the requirements of the Directive 2008/50/EC: Agglomeration-Sofia (code of the area BG0001); Agglomeration-Plovdiv (BG0002); Agglomeration-Varna (BG0003); North/Danubian (BG0004); South-Western (BG0005); South-Eastern (BG0006). During the selected time period, Devnya Municipality reached compliance with the norms for $\mathrm{PM}_{10}$. Radnevo was excluded from the study due to insufficient data coverage.

Processing the $\mathrm{PM}_{10}$ data

The European legislation provides regulations concerning the limit values of $\mathrm{PM}_{10}$ concentration in the ambient air. The norms are defined in conformity with the European ambient air quality directive Directive 2008/50/EC, which is transposed in the Bulgarian national legislation (Ordinance No 12/15.07.2010). In this work, the limit values for $\mathrm{PM}_{10}$ for protecting human health were considered. Accordingly, the following indicators were used: (a) the total daily norm (TDN) of $50 \mu \mathrm{g} / \mathrm{m}^{3}$ of air (for one day period of 24 hours), which should not be exceeded more than 35 times a year; (b) the mean annual norm (MAN), which limits the $\mathrm{PM}_{10}$ concentration up to $40 \mu \mathrm{g} / \mathrm{m}^{3}$ of air within a calendar year. According to the same legislation acts, in areas where $\mathrm{PM}_{10}$ limit values are exceeded, the relevant member state must elaborate long and short term action plans to ensure compliance with the Directive 2008/50/EC.

As mentioned above, only officially posted monitoring data were processed for the purposes of the present study. Mainly monitoring stations (MS) based on Beta ray attenuation or gravimetric methods with the required in the Directive 2008/50/EC daily data coverage were observed between 2011 and 2016. The cases with exceptions due to technical incompliance were neglected when possible or analyzed, considering the lower data reliability. All data used was measured and analyzed through the National Ambient Air Quality Control Automated System (NAAQCAS) of the Ministry of Environment and Water.

Thus, herein the annual summary of the total daily number of $P M_{10}-T D N$, at the relevant MS, was obtained as the sum of the four values published in the ExEA reports for the four quarters of each year (2011-2016). The units were held unchanged (number).

Furthermore, the MAN of $P M_{10}$ was determined as the arithmetic mean from the data collected at each MS and published in the ExEA reports for the four quarters of each year (2011-2016), if available. Note that the same procedure is proposed by the ExEA and discussed in GREENTECH.BG - Press release (2017). Again, the units remained unchanged $\left(\mu \mathrm{g} / \mathrm{m}^{3}\right)$.

In summary, the obtained values for the TDN and the MAN are natural (positive) integers and were rounded as follows: up to the second sign after the decimal point for the MAN values and up to the decimal point for the TDN values.

Benchmarking analyses has been applied for obtaining the range of discrepancies and the tendencies of the $\mathrm{PM}_{10}$ concentrations, monitored at different MS that have been in operation and capable for providing representative data during the investigated period.

\section{Results and discussion}

Previous studies as discussed in ETC/ACM (2013), and the publications mentioned on the topic therein, have observed the existence of a strong correlation between the annual average concentration and the number of days when the $50 \mu \mathrm{g} / \mathrm{m}^{3}$ daily limit value is exceeded. The current investigation has confirmed the previous observations that the TDN is almost never exceeded if the MAN is not (see Figures 1 and 2). The authors in ETC/ACM (2013) have proposed that this nearly linear relationship between the two variables is sufficient for assessment of emission reduction strategies (e.g. using modeling) that are based on the annual mean $\mathrm{PM}_{10}$ concentrations for addressing the exceedances of daily and yearly limit values. This approach is adopted also in the Directive 2008/50/EC.

In an independent study Kiesewetter (2015) where the annual mean concentrations and the $36^{\text {th }}$ highest daily average concentration for 2009 were reviewed (data source - AirBase), the authors have 
concluded that the limit on the daily exceedance of $50 \mu \mathrm{g} / \mathrm{m}^{3}$ is well represented and almost never exceeded when the annual mean limit is up to $30 \mu \mathrm{g} / \mathrm{m}^{3}$.

In the present work, the mean number of days with exceeded $\mathrm{PM}_{10}$ limit values, namely the indicator TDN was plotted versus the MAN of the $\mathrm{PM}_{10}$, regarding urban background (UB) MS. The results were summarized in Figure 1, which confirmed the hypothesis discussed by ETC/ACM (2013) and Kiesewetter (2015) with minor exclusions. Unfortunately, the majority of the data points are showing significant exceedance in terms of both studied indicators. Those reflecting a MAN between 30 and 40 $\mu \mathrm{g} / \mathrm{m}^{3}$ exceed in more than $99 \%$ of the cases the TDN. However, most of the data, obtained in 2015 and 2016 obey MAN values between 20 and $50 \mu \mathrm{g} / \mathrm{m}^{3}$, which is reflected in the significantly lower values for the TDN.

Figure 1: Annual total number of days exceeding the limit value of $\mathrm{PM}_{10}-\mathrm{TDN}\left(50 \mu \mathrm{g} / \mathrm{m}^{3}\right.$, not to be exceeded more than 35 times a year) versus the mean annual $\mathrm{PM}_{10}$ concentration - MAN (not to exceed $40 \mu \mathrm{g} / \mathrm{m}^{3}$ a year) that are experimentally measured by the ExEA at the Urban background measuring stations

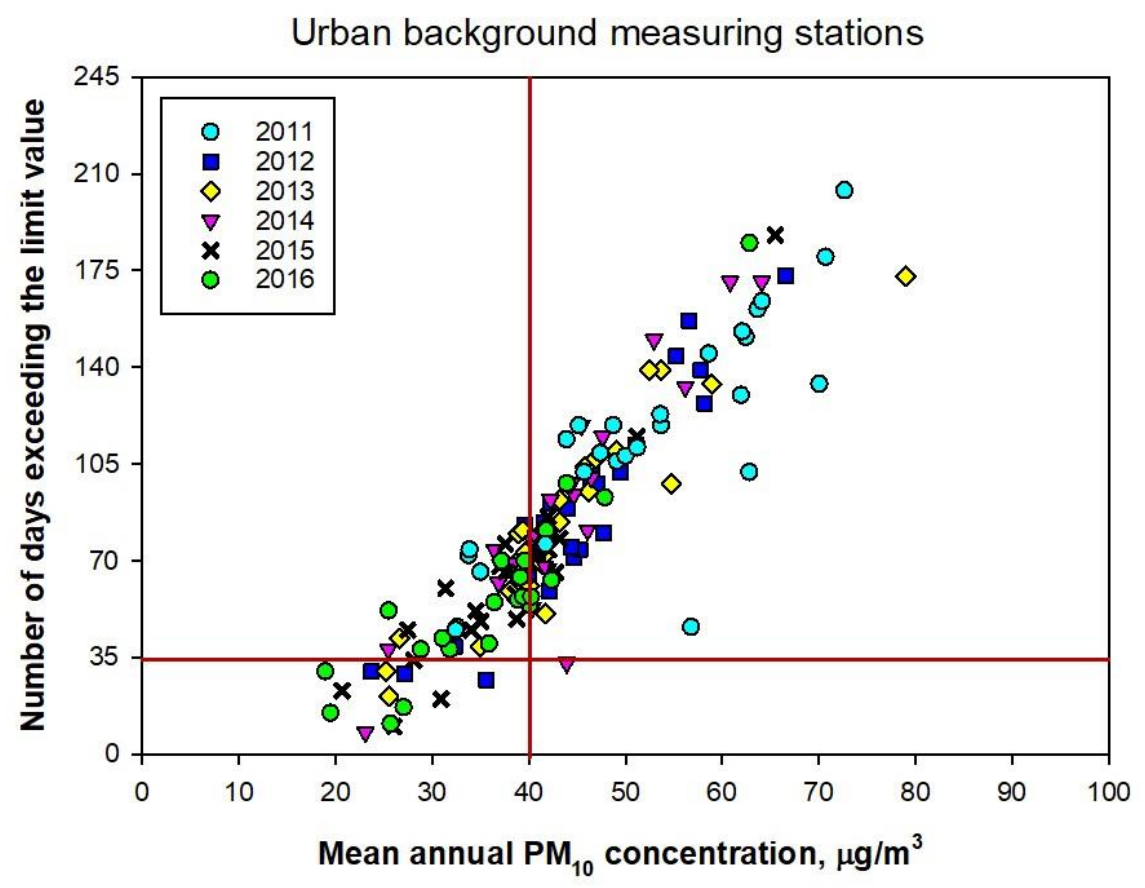

Source: ExEA (2011-2016) and authors (2018)

Preliminary results of a parallel critical review of the municipal ambient air quality plans in the country showed that air quality modeling, relying mainly on the annual mean values of the two $\mathrm{PM}_{10}$ indicators is insufficient when analyzing the genesis of episodes and characterizing the influence of the atmospheric conditions (e.g. meteorology, emissions, boundary conditions etc.) that would lead to temporarily very high $\mathrm{PM}_{10}$ concentrations in the ambient air. Moreover, typically significant uncertainty is expected, when applying dispersion modeling, which should be obtained according to the Directive 2008/50/EC. Besides that, the implementation of different dispersion models often allows neglecting critical/significant $\mathrm{PM}_{10}$ sources, which additionally compromises the accuracy and the reliability of the resulted assessment of the ambient air quality. A possible way to overcome the issue is having a detailed emission inventory (preferably based on a bottom-up approach) at the municipal level, accounting for all possible emission sectors and in parallel to apply receptor modeling for detailed source apportionment. Despite the chosen methods, one should keep in mind that the results strongly depend on the quality of the used input data. 


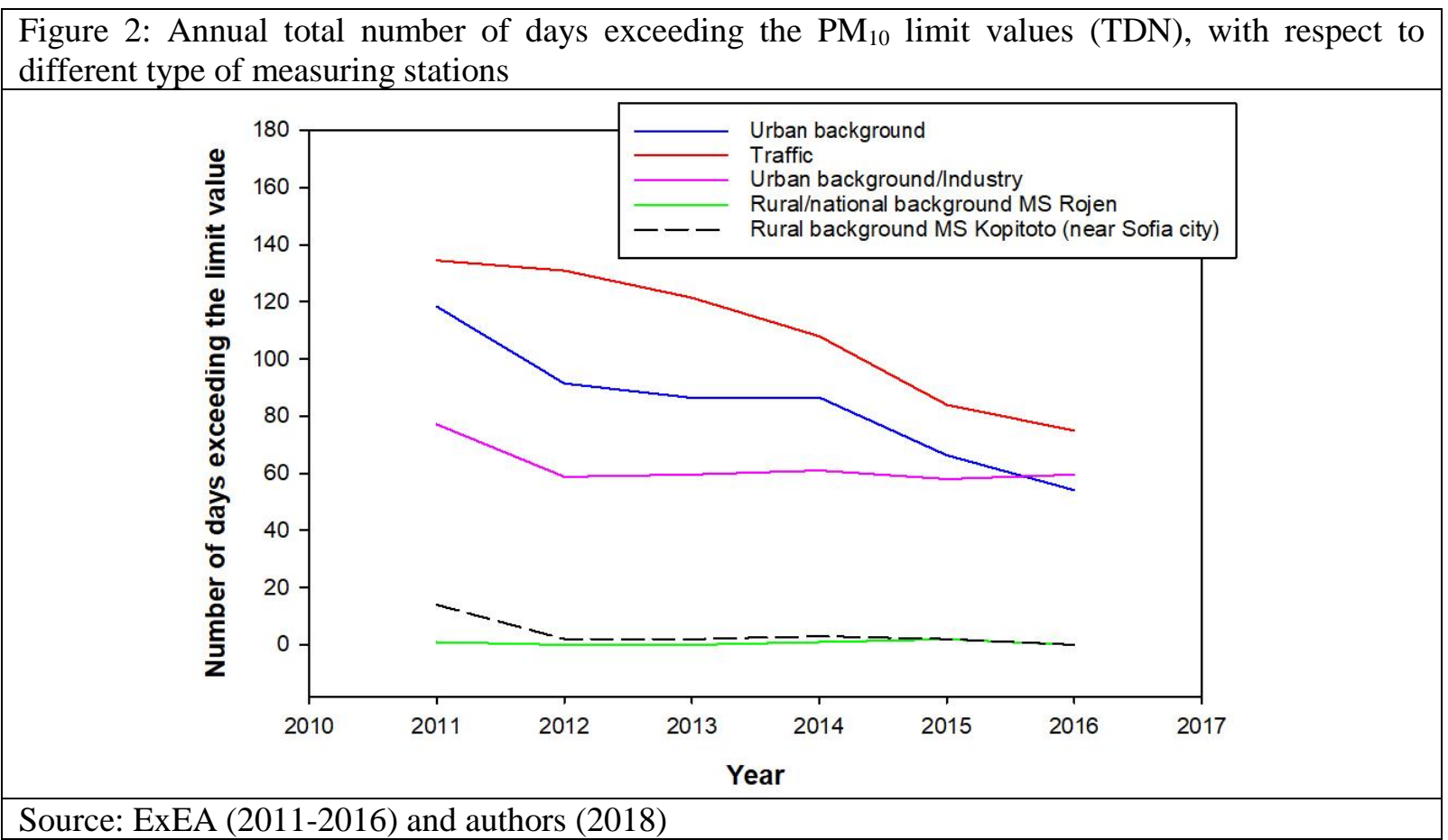

Figure 3: Seasonal effect on the TDN at Urban background (UB), Traffic (T), and combined: Traffic/Urban background (T/UB) and Industry/Urban background (I/UB) measuring stations across the country

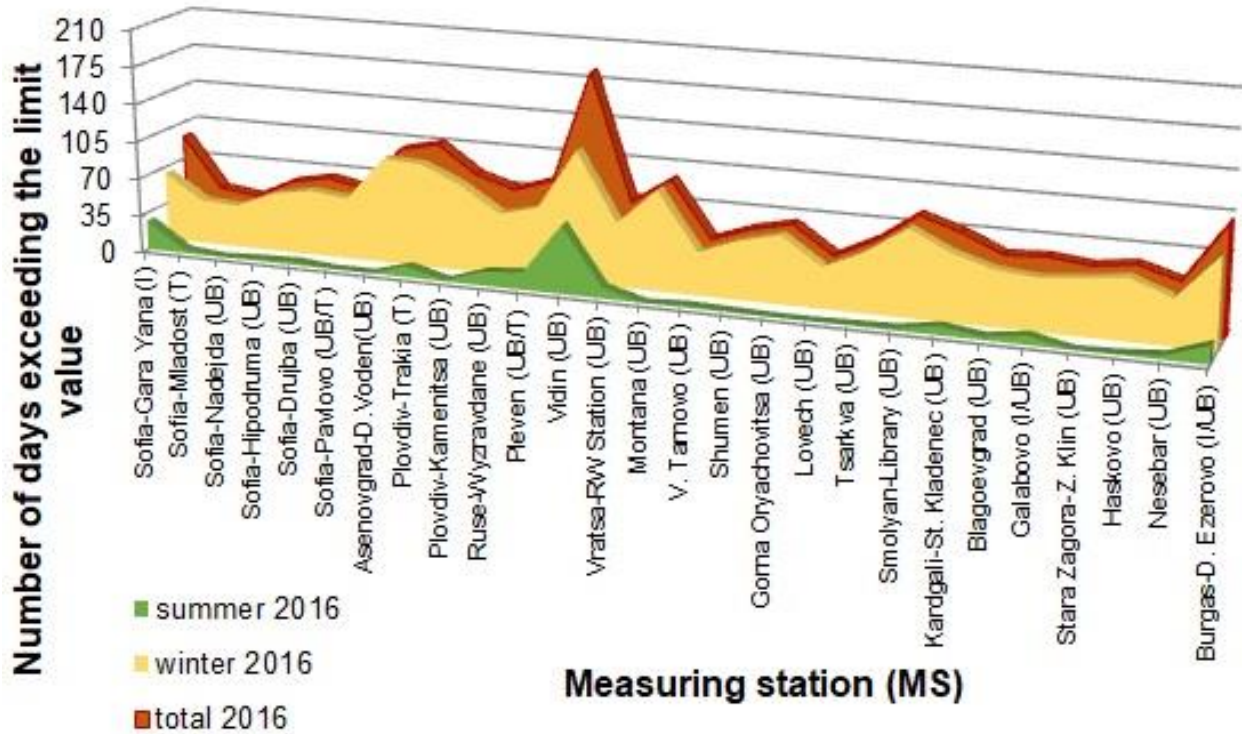

Source: ExEA (2016) and authors (2018)

The annual total nuber of days, exceeding the $\mathrm{PM}_{10}$ limits TDN at different type of the MS available at the NAAQCAS is summarized in Figure 2, for the same period 2011-2016. A similar plot can be seen in the NRSPE (2017), where no data for 2016 is available. A tendency was observed for decreasing the exceedance at the MS of type: UB and traffic (T). However, the $\mathrm{T}$ stations showed the highest measured TDN, while in 2016 the UB denoted value lower that the one, measured at the UB/Industry type of MS. In addition, at all type of stations, the limit value was exceeded (about two to three times) except at the two rural background MS investigated here. However, a comparison was done of the NRSPE (2017), which is based on data relevant for the year 2015 with the NRSPE (2015), based on data relevant for 2013. Thus, it was found that the $\mathrm{PM}_{10}$ emitted from the sector residential heating, which is believed to have the most prominent impact on the $\mathrm{PM}_{10}$, measured at UB stations, are as 
follows: for 2015 the value is $23,11 \times 10^{3}$ tone/year (at total annual $\mathrm{PM}_{10}$ emissions of $50,02 \times 10^{3}$ tone/year) for 2013 , it is $24.99 \times 10^{3}$ tone/year (at total annual $\mathrm{PM}_{10}$ emissions of $42.44 \times 10^{3}$ tone/year). The major increase of the $\mathrm{PM}_{10}$ emissions in the NRSPE (2017) report is in the sector noncombustible industrial processes and product use. The role of the residential heating is of course significant during the winter period, which is often accompanied by the occurrence of particular atmospheric conditions e.g. inversion; low or high wind velocity etc.

The seasonal interpretation of the TDN for the year 2016 is presented in Figure 3. Thus, the observed $\mathrm{PM}_{10}$ exceedance showed behavior, typically observed in many European cities. The seasonal $\mathrm{PM}_{10}$ variation in Figure 3 corresponds with the findings in an independent study by Gadzheva (2013). It shows a detailed numerical investigation of the phenomena driving the local to regional atmospheric pollution transport and transformation processes over Bulgaria and the Balkan region. The main pathways and processes leading to a particular atmospheric composition in the region (accounting also the heterogeneous chemistry) are also foreseen. The study covers the years 2000-2007 and involves four emission scenarios with a large number of pollutants, including biogenic, except those arising from energy and road transport sectors. The authors pointed out that the fine PM have their minimum during daytime and their concentrations for the cold seasons (autumn, winter) are higher than those for the warm seasons (spring, summer).

\section{Conclusion}

The present study briefly summarizes the current state of the $\mathrm{PM}_{10}$ exceedance at the affected municipalities in the country. Based on benchmarking analyses of officially reported and freely accessible data, the range of discrepancies and the tendencies in the ambient air $\mathrm{PM}_{10}$ concentrations were investigated. The work covers a relatively short period and does not pretend to be a detailed and full-factor analysis of the problem. However, the summarized results seem to correspond well with the hypothesis, described in the national environmental reports from the investigated time interval that the sectors residential heating and the transport are dominating the $\mathrm{PM}_{10}$ emissions during the winter period in the large and medium sized urban centers. Because the scope of the study is too narrow it cannot explain the intensive $\mathrm{PM}_{10}$ exceedance in the Municipality of Vratsa, which was observed e.g. during the summer of 2016. The case needs separate study involving source apportionment.

\section{Acknowledgment}

The work was elaborated in the frame of COST Action CM 1404 and was financially supported through Contract DKOST01/13 for national co-funding of the National Science Fund,Ministry of Education and Science. The author Tsvetelina Petrova was supported by the project No BG05M2OP001-2.009-0033 "Promotion of Contemporary Research Through Creation of Scientific and Innovative Environment to Encourage Young Researchers in Technical University - Sofia and The National Railway Infrastructure Company in The Field of Engineering Science and Technology Development" within the Intelligent Growth Science and Education Operational Programme cofunded by the European Structural and Investment Funds of the European Union.

\section{References}

EEA (2017) Emissions of the main air pollutants in Europe. Report. https://www.eea.europa.eu/data-andmaps/indicators/main-anthropogenic-air-pollutant-emissions/assessment-5.

Schmidt, K.-G. and Zellner R. (2010, September) Feinstaub, Statuspapier. ISBN: 978-3-89746-120-8, https://dechema.de/dechema_media/Statuspapier_Feinstaub-p-3396-view_image-1-called_by-dechema-original_sitedechema_eV-original_page-124930.pdf.

Dimitriou, K., \& Kassomenos, P. (2017) Airborne heavy metals in two cities of North Rhine Westphalia - Performing inhalation cancer risk assessment in terms of atmospheric circulation. Chemosphere, 186, 78-87.

http://dx.doi.org/10.1016/j.chemosphere.2017.07.138.

Colom-Díaz, J.M., Alzueta, M. U., Fernandes, U., Costa, M. (2017) Emissions of polycyclic aromatic hydrocarbons during biomass combustion in a drop tube furnace. Fuel 207, 790-800 http://dx.doi.org/10.1016/j.fuel.2017.06.084.

WHO (2005) Air quality guidelines for particulate matter, ozone, nitrogen dioxide and sulfur dioxide. Global update 2005. Summary of risk assessment.

http://apps.who.int/iris/bitstream/handle/10665/69477/WHO_SDE_PHE_OEH_06.02_eng.pdf;jsessionid=F9E51C972E6B82 306A175191188E88F4?sequence $=1$.

Directive 2008/50/EC of the European Parliament and of the Council, of 21 May 2008, on ambient air quality and cleaner air for Europe. https://eur-lex.europa.eu/legal-content/en/ALL/?uri=CELEX:32008L0050. 
EEA (2015) Exceedance of air quality standards in urban areas. Report. https://www.eea.europa.eu/data-andmaps/indicators/exceedance-of-air-quality-limit-3/assessment.

Megido, L., Suarez-Pena, B., Negral L., Castrillon, L., Suarez, S. Fernandez-Nava, Y. and Maranon E. (2016) Relationship between physico-chemical characteristics and potential toxicity of PM10. Chemosphere 162, 73-79. http://dx.doi.org/10.1016/j.chemosphere.2016.07.067.

Chernyshev, V.V., Zakharenko, A.M., Ugay, S.M., Hien, T.T., Hai, L.H., Kholodov, A.S., Burykina, T.I., Stratidakis, A.K., Mezhuev, Ya O., Tsatsakis, A.M., Golokhvast, K.S. (2018) Morphologic and chemical composition of particulate matter in motorcycle engine exhaust. Toxicology Reports 5, 224-230. http://dx.doi.org/10.1016/j.toxrep.2018.01.003.

Czech, H., Miersch, T., Orasche, J., Abbaszade, G., Sippula, O., Tissari, J., Michalke, B., Schnelle-Kreis, J., Streibel, Th., Jokiniemi, J., Zimmermann, R. (2018) Chemical composition and speciation of particulate organic matter from modern residential small-scale wood combustion appliances. Science of the Total Environment 612, 636-648 http://dx.doi.org/10.1016/j.scitotenv.2017.08.263.

NRSPE (2017) National Report on the Status and the Protection of the Environment of Bulgaria 2017 http://eea.government.bg/bg/soer/2015.

European Commission (EC) - Press release (2018) Air quality: Commission takes action to protect citizens from air pollution, Brussels, 17 May 2018, http://europa.eu/rapid/press-release_IP-18-3450_en.htm.

EEA (2017a), Air pollutant emissions data viewer 2017 https://www.eea.europa.eu/data-and-maps/dashboards/air-pollutantemissions-data-viewer.

IIR (2017) Bulgaria's Informative Inventory Report 2017, http://eea.government.bg/bg/dokladi/clrtap.

IIR (2018) Bulgaria's Informative Inventory Report 2018,

http://www.ceip.at/ms/ceip_home1/ceip_home/status_reporting/2018_submissions/.

NFR tables (2017) National Inventory on Air Pollutants reported as NFR tables, 2017,

http://www.ceip.at/ms/ceip_home1/ceip_home/status_reporting/2017_submissions/.

NFR tables (2018) National Inventory on Air Pollutants reported as NFR tables, 2018, http://www.ceip.at/ms/ceip_home1/ceip_home/status_reporting/2018_submissions/.

Directive 2016/2284/EU of the European Parliament and of the Council of 14 December 2016 on the reduction of national emissions of certain atmospheric pollutants, amending Directive 2003/35/EC and repealing Directive 2001/81/EC, https://eur-lex.europa.eu/legal-content/EN/TXT/?uri=uriserv\%3AOJ.L_.2016.344.01.0001.01.ENG.

Tista, M., Wankmueller, R., Marecko, K. (2017) Methodologies applied to the CEIP GNFR gap-filling (2017) Part III: Main pollutants and Particulate Matter (NOx, NMVOCs, SOx, NH3, CO, PM2.5, PM10, PMcoarse). CEIP Umweltbundesamt, Technical report CEIP 03-3/2017, http://www.ceip.at/fileadmin/inhalte/emep/pdf/2017/MAIN__PM_gapfilling_documentation_2017.pdf.

ETC/ACM (2013, November) How to start with PM modeling for air quality assessment and planning relevant to the Air Quality Directive. ETC/ACM Technical Paper 2013/11, ETCACM_TP_2013_11_FAIRMODE_guide_modelling_PM.pdf.

Ministry of Environment and Water of Bulgaria (MOEW), http://www.moew.government.bg/bg/vuzduh/kachestvo-naatmosferniya-vuzduh/normativni-aktove/.

Environment and Water Executive Agency (ExEA), http://eea.government.bg/bg/dokladi.

EMEP/EEA (2016) air pollutant emission inventory guidebook, https://www.eea.europa.eu/publications/emep-eeaguidebook-2016.

Baumbach, G., Baumann, K., Droescher, F., Gross, H., Steisslinger, B. (1990) Luftreinhaltung, Enstehung, Ausbreitung und Wirkung von Luftreinigungen-Messtechnik, Emissionsminderung und Vorschriften, Springer-Verlag Berlin Heidelberg New York, ISBN 3-540-52677-3.

Warnatz, J., Maas, U., Dibble, R.W. (2006) Physical and chemical fundamentals, modeling and simulation, experiments, pollutant formation, 4th Edition. Springer-Verlag Berlin, Heidelberg, ISBN-10 3-540-25992-9 and ISBN-13 978-3-54025992-3.

Agafonov, G.L., Naydenova, I., Vlasov P.A., Warnatz, J. (2007) Detailed kinetic modeling of soot formation in shock tube pyrolysis and oxidation of toluene and n-heptane. Proceedings of the Combustion Institute 31, 575-583. http://dx.doi.org/10.1016/j.proci.2006.07.191.

Zobel, N., and Anca-Couce, A. (2013) Slow pyrolysis of wood particles: Characterization of volatiles by Laser-Induced Fluorescence. Proceedings of the Combustion Institute 34, 2355-2362 http://dx.doi.org/10.1016/j.proci.2012.06.130.

Faravelli, T., Frassoldati, A., Hemings, E.B., Ranzi, E. (2013) Multistep Kinetic Model of Biomass Pyrolysis, In Book: Cleaner Combustion, Developing Detailed Chemical Kinetic Models, Battin-Leclerc F., Simmie, J. M., Blurock, E. (Eds.), Springer-Verlag London, 111-139, http://dx.doi.org/10.1007/978-1-4471-5307-8_5.

Jones, J.M., Lea-Langton, A.R., Ma L., Pourkashanian, M., Williams, A. (2014) Combustion of Solid Biomass: Classification of Fuels, In Book: Pollutants Generated by the Combustion of Solid Biomass Fuels, Springer-Verlag London, http://dx.doi.org/10.1007/978-1-4471-6437-1.

Branco, V. and Costa, M. (2017) Effect of particle size on the burnout and emissions of particulate matter from the combustion of pulverized agricultural residues in a drop tube furnace. Energy Conversion and Management 149, 774-780 http://dx.doi.org/10.1016/j.enconman.2017.03.012. 
Wang, G., Silva, R.B., Azevedo, J.L.T., Martins-Dias, S., Costa, M. (2014) Evaluation of the combustion behaviour and ash characteristics of biomass waste derived fuels, pine and coal in a drop tube furnace. Fuel 117, 809-824. http://dx.doi.org/10.1016/j.fuel.2013.09.080.

H. Bockhorn, A. D’Anna, A. F. Sarofim, H. Wang, (2009) Combustion Generated Fine Carbonaceous Particulates, Proceedings of an International Workshop held in Villa Orlandi, Anacapri, May 13-16, 2007, KIT Scientific Publishing. ISBN: 978-3-86644-441-6.

Fuzzi, S., Baltensperger, U., Carslaw, K., Decesari, S., Denier van der Gon, H., Facchini, M. C., Fowler, D., Koren, I., Langford, B., Lohmann, U., Nemitz, V., Pandis, S., Riipinen, I., Rudich, V., Schaap, M., Slowik, J. G., Spracklen, D. V., Vignati, E., Wild, M., Williams, M. and Gilardoni, S. (2015) Particulate matter, air quality and climate: lessons learned and future needs Atmos. Chem. Phys., 15, 8217-8299. http://dx.doi.org/10.5194/acp-15-8217-2015.

Dallmann, T. R., Onasch, T. B., Kirchstetter, T. W., Worton, D. R., Fortner, E. C., Herndon, S. C., Wood, E. C., Franklin, J. P., Worsnop, D. R., Goldstein, A. H., and Harley, R. A. (2014) Characterization of particulate matter emissions from on-road gasoline and diesel vehicles using a soot particle aerosol mass spectrometer. Atmos. Chem. Phys., 14, 7585-7599. http://dx.doi.org/10.5194/acp-14-7585-2014.

Wardoyo, A.Y.P., Unggul, P.J., Noor, J.A.E. (2018) Varied dose exposures to ultrafine particles in the motorcycle smoke cause kidney cell damages in male mice. Toxicology Reports 5, 383-389. http://dx.doi.org/10.1016/j.toxrep.2018.02.014 Bruckmann, P., Birmili, W., Straub, W., Pitz, W., Gladtke, D., Pfeffer, U., Hebbinghaus, H., Wurzler, S., Olschweski, A. (2008) An outbreak of Saharan dust causing high PM10 levels north of the Alps. Gefahrstoffe Reinhaltung der Luft 68, 490498.

Lipsky. E. M., Pekney, N. J., Walbert, G. F., O'Dowd, W. J., Freeman, M.C., Robinson. A. (2004) Effects of dilution sampling on fine particle emissions from pulverized coal combustion, Aerosol Science and Technology 38(6), 574-587. http://dx.doi.org/10.1080/02786820490479851.

Bressi, M., Sciare, J., Ghersi, V., Bonnaire, N., Nicolas, J.B., Petit, J.-E., Moukhtar, S., Rosso, A., Mihalopoulos, N., and Feron, A. (2013) A one-year comprehensive chemical characterization of fine aerosol (PM2.5) at urban, suburban and rural background sites in the region of Paris (France). Atmos. Chem. Phys. 13, 7825-7844. http://dx.doi.org/10.5194/acp-13-78252013.

Veleva, B., Hristova E., Nikolova, E., Kolarova, M., Valcheva, R. (2014) Seasonal variation of PM10 elemental composition in urban environment. Journal of International Scientific Publications: Ecology and Safety 8, 265-275. ISSN 1314-7234 (Online).

Manousakas, M., Diapouli, E., Papaefthymiou, H., Migliori, A., Karydas, A.G., Padilla-Alvarez, R., Bogovac, M., Kaiser, R.B., Jaksic, M., Bogdanovic-Radovic, I., Eleftheriadis K., (2015) Source apportionment by PMF on elemental concentrations obtained by PIXE analysis of PM10 samples collected at the vicinity of lignite power plants and mines in Megalopolis, Greece, Nuclear Instruments and Methods in Physics Research Section B: Beam Interactions with Materials and Atoms 349, 114-124. http://dx.doi.org/doi:10.1016/j.nimb.2015.02.037.

Yatkin, S., Belis, C.A., Gerboles, M., Calzolai, G., Lucarelli, F., Cavalli, F., Trzepla, K. (2016) An interlaboratory comparison study on the measurement of elements in PM10. Atmospheric Environment 125 (A), 61-68. http://dx.doi.org/10.1016/j.atmosenv.2015.10.084.

Vicente, E.D., Alves, C.A. (2018) An overview of particulate emissions from residential biomass combustion. Atmospheric Research 199, 159-185. http://dx.doi.org/10.1016/j.atmosres.2017.08.027.

Xie, Y., Zhao, B., Zhang L., Luo, R. (2015) Spatiotemporal variations of PM2.5 and PM10 concentrations between 31 Chinese cities and their relationships with SO2, NO2, CO and O3. Particuology 20, 141-149. http://dx.doi.org/10.1016/j.partic.2015.01.003

Süring, K., Bach, S., Bossmann, K., Wolter, E., Neumann, A., Straff, W., Höflich, C. (2016) PM10 contains particle-bound allergens: Dust analysis by Flow Cytometry. Environmental Technology \& Innovation, In Press, will appear in January Environmental Technology \& Innovation 5, 60-66. http://dx.doi.org/10.1016/j.eti.2016.01.00.

Belis, C., Georgieva, E., Janos, O., Sega, K., Törok, S., Veleva, B., Perrone, M., Vratolis, S., Pernigotti, D., Eleftheriadis, K. A. (2015) JRS Technical Report. Comparative analysis of the causes of air pollution in three cities of the Danube region: Implications for the implementation of the air quality directives. EUR 27712 EN. doi:10.2788/73231.

Karagulian, F., Belis, C. A., Dora, C.F.C., Prüss-Ustün, A.M., Bonjour, S., Adair-Rohani, H., Amann, M. (2015) Contributions to cities' ambient particulate matter (PM): A systematic review of local source contributions at global level. Atmospheric Environment 120, 475-483. http://dx.doi.org/10.1016/j.atmosenv.2015.08.087.

Bruchmueller, J., Luo, K.H., van Wachem, B.G.M. (2013) Tar formation variations during fluidised bed pyrolytic biomass conversion. Proceedings of the Combustion Institute 34, 2373-2381. http://dx.doi.org/10.1016/j.proci.2012.06.054.

Wen, C., Xu, M., Yu, D., Sheng, C., Wuc, H., Zhang, P., Qiao, Y., Yao, H., (2013) PM10 formation during the combustion of N2-char and CO2-char of Chinese coals. Proceedings of the Combustion Institute 34, 2383-2392. http://dx.doi.org/10.1016/j.proci.2012.07.080.

Nielsen, I. E., Eriksson, A. C., Lindgren, R., Martinsson, J., Nystroem, R., Nordin, E. Z., Sadiktsis, I., Boman, C., Nøjgaard, J. K., Pagels, J. (2017) Time-resolved analysis of particle emissions from residential biomass combustion e Emissions of refractory black carbon, PAHs and organic tracers. Atmospheric Environment 165, 179-190. http://dx.doi.org/10.1016/j.atmosenv.2017.06.033. 
Ahlm. L., Julin. J., Fountoukis. C., Pandis. S. N., Riipinen, I. (2013) Particle number concentrations over Europe in 2030: the role of emissions and new particle formation, Atmos. Chem. Phys. 13, 10271-10283. http://dx.doi.org/10.5194/acp-1310271-2013.

Gadzheva, G.K., Ganeva, K.G., Miloshev, N.G., Syrakov, D. E., (2013) Prodanova, M. Numerical study of the atmospheric composition in Bulgaria. Computers and Mathematics with Applications 65, 402-422. http://dx.doi.org/10.1016/j.camwa.2012.07.002.

Fuzzi, S., Andreae, M., Huebert, B.J., Kulmula, M., Bind, T.C., Doherty, S.J., Guenther, A., Kanakidou, M., Kawamura, K., Kerminen, V.-M., Lohmann, U., Poeschl, U., Russell, L.M. (2006) Critical assessment of the current state of scientific knowledge, terminology, and research needs concerning the role of organic aerosols in the atmosphere, climate, and global change. Atmos. Chem. Phys. 6, 2017-2038. www.atmos-chem-phys.net/6/2017/2006/.

ExEA (2011-2016) Environment and Water Executive Agency, Archives of a three-monthly bulletin for the condition of the ambient air in Bulgaria, www.eea.government.bg/bg/dokladi/arhiv_trim-bul.

GREENTECH.BG - Press release (2017), https://greentech.bg/archives/70266)green.

NRSPE (2015) National Report on the Status and the Protection of the Environment of Bulgaria 2015 http://eea.government.bg/bg/soer/2013. 